\title{
Multidrug-Resistant Tuberculosis: Review of the Literature from A Case of Choroidal Granuloma Associated with a Pott's Disease Secondary to a Pulmonary Localization
}

Pépin Williams Atipo-Tsiba ${ }^{1 *}$, Omgbwa Eballe ${ }^{2}$, Reinette Messe Ambia Koulimaya ${ }^{1}$, Sarah Bel'hantier ${ }^{1}$, Ibrahim Abib Diomandé ${ }^{3}$ and Alex Mouinga Abayi ${ }^{4}$

${ }^{1}$ Ophthalmology department, University Hospital of Brazzaville, Congo

${ }^{2}$ Ophthalmology department, Laquintinie Hospital of Douala, Cameroon

${ }^{3}$ Ophthalmology department, University Hospital of Bouaké, Ivory Coast

${ }^{4}$ Ophthalmology department, Hospital of the instructions of the armies of Libreville, Gabon

Submission: July 14, 2017; Published: August 23, 2017

*Corresponding author: Atipo-Tsiba PW, MD, FMH, FEBO, Assistant Professor -Marien Ngouabi, Head of Ophthalmology department, University Hospital of Brazzaville, Congo, Email: atipo.kani@gmail.com/williams.atipo@yahoo.fr

\begin{abstract}
Multidrug-resistant tuberculosis (MDR-TB) is due to resistance of Koch's Bacillus to Rifampicin and / or Isoniazid. Another therapeutic protocol called second line is necessary. It combines in attack phase ( 6 months) an aminoside, a fluoro quinolone, Ethionamide and Pyrazinamide. The maintenance phase (12 to 18 months) is constituted by a fluoroquinolone, Ethionamide, and Pyrazinamide. Ethambutol may be associated with both phases if the genetic analyzes prove that it is active on the causal strain. New molecules (Bedaquiline, Delamanide) are already in use in so-called ultra-resistant forms when the second classical line is ineffective. All these drugs are not part of the national tuberculosis programs. Their cost is a real brake in Africa. The aim of this work was to examin literature review on MDR-TB from a case with pulmonary, bone and ocular involvement.
\end{abstract}

Keywords: Multidrug-resistant; Rifampicin; Isoniazid; Pyrazinamide; Ethambutol; Fluoroquinolone; Aminoside; Bedaquiline; Delamanide

\section{Introduction}

Multidrug-resistant tuberculosis (MDR-TB) is defined as a form of a Koch's bacillus strain resistant to Rifampicin and / or Isoniazid [1]. These two molecules constitute the major drugs of the first line that they form in association with Pyrazinamide and Ethambutol. This resistance may be primary when the patient has never received an anti-tuberculosis medication or secondary if the patient has already been treated for tuberculosis [2-4]. In case of resistance a second line of drugs is necessary. It combines an aminoside (Kanamycin, Amikacin, Capreomycin), a fluoroquinolone (Ofloxacin, Moxifloxacin), thionamide and Pyrazinamide. The maintenance phase (12 to 18 months) is constituted by a fluoro quinolone, Ethionamide and Pyrazinamide. Ethambutol may be associated if genetic testing proves that it is active on the causal strain. Bedaquiline and Delamanide are used in so-called ultra-resistant forms when the second classical line is in effective [5-7]. This work makes a short review of the literature on MDR-TB from a clinical form with a multi focal localization.

\section{Case Details}

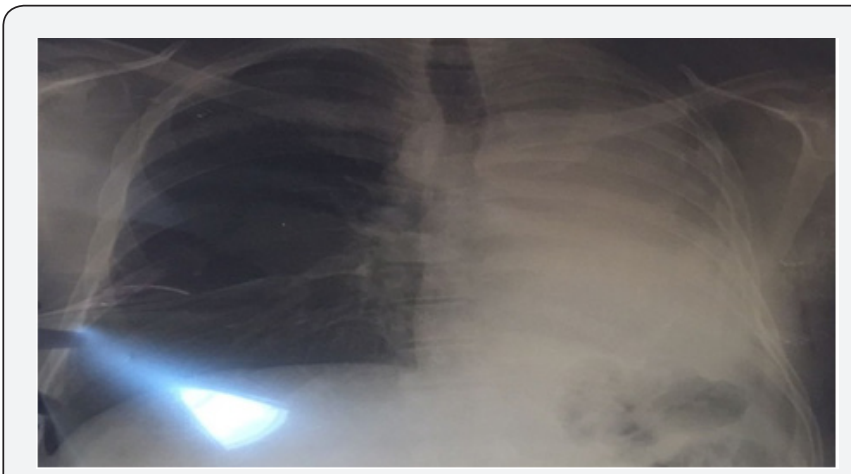

Figure 1: Pneumopathy due to tuberculosis. 


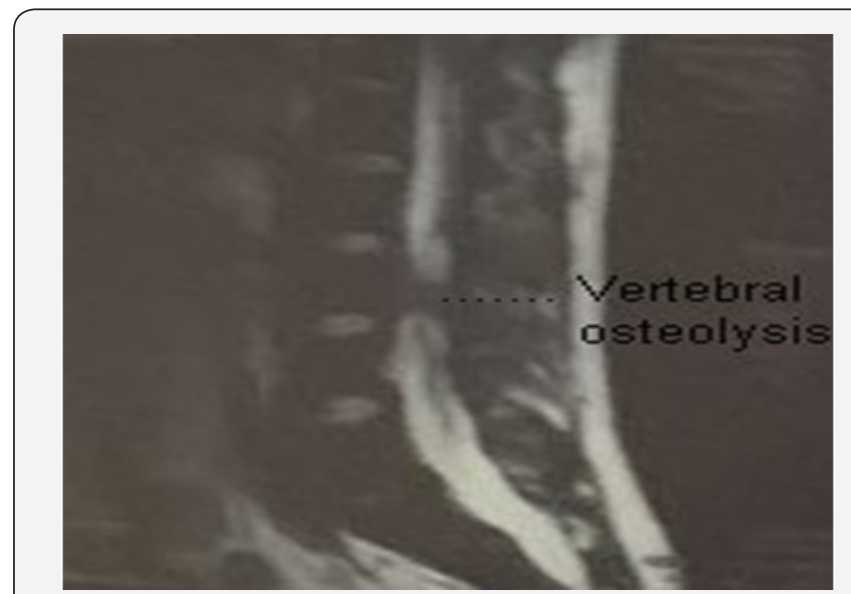

Figure 2: Pott's disease due to lysis of dorsal vertebraes.

A patient aged 25 was seen for a decline of right visual acuity evolving for a week. He takes a tuberculosis treatment (Rifampicin, Isoniazid, Pyrazinamide, Ethambutol) since 4 months due to left pneumopathy (Figure 1). This visual decrease was preceded by a paraplegia following a Pott's disease due to lysis of dorsal vertebraes (Figure 2).

His ophthalmological review noted

1. Right eye: no ligth perception, clear cornea, panuvéite with an important vitritis making the fundus difficult, ocular tonus $12 \mathrm{~mm} \mathrm{Hg}$.

2. Left eye: visual acuity at $20 / 20$ without correction, normal ocular structures, ocular tonus $13 \mathrm{~mm} \mathrm{Hg}$.

Ultrasound showed a choroidal granuloma and total detachment of the retina (Figure 3). PCR revealed the presence of Koch's bacillus DNA in the vitreous. HIV serology was negative. Retinal fluorescein angiography was not performed because of the vitreous blur. The diagnosis of multifocal tuberculosis was retained. A program for the readjustment of anti tuberculosis treatment has been planned. The proposed protocol was formed during the attack phase by Ethionamide, Ofloxacin, Amikacin and Pyrazinamide. This protocol could not be realized because the patient has not returned to the hospital.

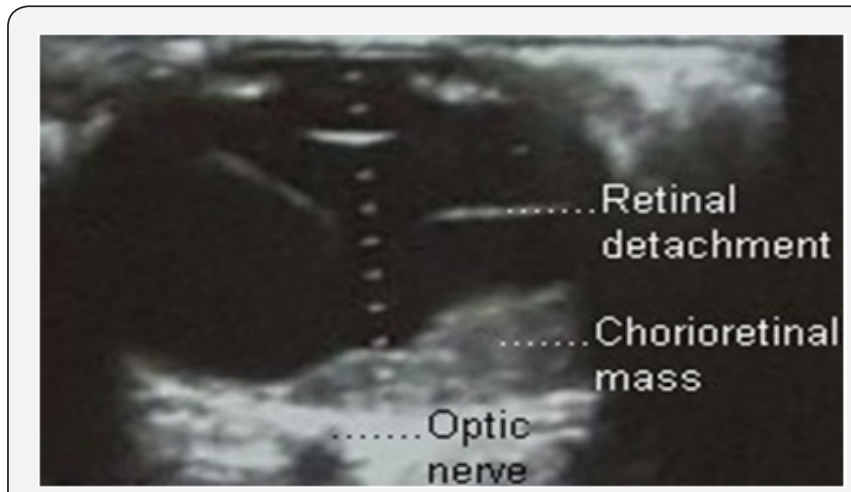

Figure 3 : Choroidal granuloma and retinal detachment in tuberculosis.

\section{Discussion}

According to the WHO the prevalence of multidrug-resistant tuberculosis (MDR-TB) is just under $1 \%$ in rich countries compared to $20 \%$ in some areas of black Africa [8,9]. Several factors may explain this, the high prevalence of HIV infection, politico-military conflicts and poverty [10-12]. The first antituberculosis drugs appeared during the Second World War. The arrival of Rifampicin in the 1970's has upset the situation. Combined with Isoniazid it has remarkable efficacy against Koch's bacillus. The four-drug combination of Rifampicin, Isoniazide, Pyrazinamide and Ethambutol is the standard treatment used by most national tuberculosis programs. So much so that it was believed in the 1980 's that tuberculosis would be eradicated before the end of the 20th century [11]. But the situation changed completely in the 1980's with the emergence of the AIDS pandemic. The clinical studies carried out at the time all prove that tuberculosis is one of the main opportunistic diseases of AIDS [13,14]. In the early 1990's the first cases of Koch bacillus strains resistant to classical antituberculosis drugs were described. These strains no longer respond to the combination of the two major antibiotics of the first line, Isoniazid and Rifampicin. A real public health problem around 250000 deaths per year have related to MDRTB $[2,4,8]$. The management of these multiresistant forms can be confronted with 3 major obstacles. First of all the diagnosis if one does not suspect the possibility of multi-resistance the affected patients will receive conventional treatments. They will remain contagious and make their bacterial strain even more resistant. Then the duration of the treatment, even with an adapted management the patients take more time to heal. A typical tuberculosis treatment lasts an average of 6 months. Treatment of MDR-TB can last up to 24 months, patients remain contagious for up to 3 months. Molecular biology and genetics have made significant progress in the typing of these resistances. They made it possible to determine in the DNA of the Koch's bacillus the genetic mutations responsable of these resistances. These are the RpoB gene for Rifampicin, and the KatG and InhA genes for Isoniazid. In the highly-resistant forms, resistance to Ethionamide and fluoroquinolones are respectively due to pncA and gyrB genes $[15,16]$. We have not found any studies on aminoside resistance. However the systematization of their use is limited by 2 things, their renal and atrial toxicity and to a lesser extent the pain induced by the repeated injections related to their administration. Indeed unlike the other antituberculosis drugs which are presented in the form of tablets aminosides exist only in injection $[7,17,18]$. Research is advancing but more slowly than hoped. In the last fifty years only two molecules have been placed on the market Bedaquiline and Delamanide less than five years ago. These drugs are active on the highly resistant strains of the Koch's bacillus [19-21]. Outside of South Africa and some Maghreb countries, entire regions of Africa do not have laboratories capables of performing the necessary analyzes in case of suspicion of MRD-TB. Second-line drugs such 
as fluoroquinolones and aminoglycosides are available, but the duration of their use significantly increases the cost of treatment by making it unattainable for the majority of patients. MDR-TB should be integrated into the overall strategy of the various national tuberculosis programs.

\section{Conflicts of Interest}

There are no conflicts of interest.

\section{References}

1. Dalcolmo MP, Andrade MK, Picon PD (2007) Multiresistant tuberculosis in Brazil: history and control. Rev Saude Publica 41 (Suppl 1): 34-42.

2. Ribeiro L, Sousa C, Sousa A, Ferreira C, Duarte R, et al. (2015) Evaluation of hearing in patients with multi resistant tuberculosis. Acta Med Port 28(1): 87-91.

3. Blanquer R, Rodrigo T, Casals M, Ruiz MJ, García GJM, et al. (2015) Resistance to first-line antituberculosis drugs in Spain, 2010-2011. RETUBES Study. Arch Bronconeumol 51(1):24-30.

4. Bermejo M, Clavera I, Michel de la Rosa F, Marín B (2007) Epidemiology of tuberculosis. An Sist Sanit Navar 30 (Suppl 2): 7-19.

5. Seaworth BJ, Griffith DE (2017)Therapy of Multidrug-Resistant and Extensively Drug-Resistant Tuberculosis. Microbiol Spectr 5(2).

6. Coll P (2009) Active drugs against Mycobacterium tuberculosis. Enferm Infecc Microbiol Clin 27(8): 474-480.

7. Van AR, Dijkstra JA, Van der MME, Borjas HJF, Kosterink JG, et al. (2017) Reduced chance of hearing loss associated with therapeutic drug monitoring of aminoglycosides in the treatment of multidrug-resistant tuberculosis. Antimicrob Agents Chemother 61(3): e01400-e01416.

8. Benfenatki N (2009) Multiresistant tuberculosis. Rev Med Interne 30 (Suppl 4): S268-S272.

9. Mounguengui D, Ondounda M, Mandji LJM, Fabre M, Gaudong L, et al (2012) Multi-resistant tuberculosis at the hôpital d'instruction des armées de Libreville (Gabon) about 16 cases. Bull Soc Pathol Exot 105(1): $1-4$

10. Ekaza E, Guessan NRK, Kacou NA, Aka N, Kouakou J, et al. (2013) Emergence in Western African countries of MDR-TB, focus on Côte dIvoire. Biomed Res Int 2013: 426709.
11. Gatey C, Bouvet E (2012) Tuberculosis treatment in adults. Rev Prat 62(4): 495-501.

12. Blomberg B (2008) Antimicrobial resistance in developing countries. Tidsskr Nor Laege foren 128(21): 2462-2466.

13. Dorronsoro I, Ojer M, Ruz A, Navascués A, Gastesi C, et al. (2005) Study of the resistance of Mycobacterium tuberculosis to the principal tuberculostatics (Hospital of Navarra 1996-2003). An Sist Sanit Navar 28(1): 29-34.

14. Katalinić-JV, Obrovac M (2004) Drug-resistant tuberculosis: resistance mechanisms and drug susceptibility of Mycobacterium tuberculosis. Acta Med Croatica 58(4): 323-328.

15. Álvarez ALM, García JM, Pérez H, Martínez GS, Gutiérrez PJJ (2017) Utility of Phenotypic and Genotypic Testing in the Study of Mycobacterium tuberculosis Resistance to First-Line Anti-Tuberculosis drugs. Arch Bronconeumol 53(4):192-198.

16. Schön T, Miotto P, Köser CU, Viveiros M, Böttger E, et al. (2017) Myco bacterium tuberculosis drug-resistance testing: challenges, recent developments and perspectives. Clin Microbiol Infect 23(3): 154-160.

17. Hervé C, Bergot E, Veziris N, Blanc FX (2015) Tuberculosis in 2015: From diagnosis to the detection of multiresistant cases. Rev Mal Respir 32(8): 784-790.

18. Lin J, Sattar AN, Puckree T (2004) An alarming rate of drug-resistant tuberculosis at Ngwelezane Hospital in northern Kwa Zulu Natal, South Africa. Int J Tuberc Lung Dis 8(5): 568-573.

19. Dolinger DL, Colman RE, Engelthaler DM, Rodwell TC (2016) Nextgeneration sequencing-based user-friendly platforms for drugresistant tuberculosisdiagnosis: A promise for the near future. Int $J$ Mycobacteriol 5 (Suppl 1): S27-S28.

20. Ramírez LM, Pascual PJF, Noguerado AA (2013) New tuberculosis drugs in resistant and multiresistant tuberculosis. Med Clin (Barc) 141(7): 306-313.

21. Costa JG, Santos AC, Rodrigues LC, Barreto ML, Roberts JA (2005) Tuberculosis in Salvador, Brazil: costs to health system and families. Rev Saude Publica 39(1): 122-128.
Your next submission with Juniper Publishers will reach you the below assets

- Quality Editorial service

- Swift Peer Review

- Reprints availability

- E-prints Service

- Manuscript Podcast for convenient understanding

- Global attainment for your research

- Manuscript accessibility in different formats

(Pdf, E-pub, Full Text, Audio)

- Unceasing customer service

Track the below URL for one-step submission

https://juniperpublishers.com/online-submission.php 